\author{
PAWE⿺ NowAK \\ Uniwersytet Pedagogiczny, Kraków, Polska • Pedagogical University of Cracow, Poland
}

\title{
Kulturowe bariery rozwoju innowacyjności polskiej gospodarki
}

\section{The cultural barriers of innovation development of the Polish economy}

\begin{abstract}
Streszczenie: Celem niniejszego opracowania jest identyfikacja przeszkód kulturowych hamujących rozwój innowacyjności polskiej gospodarki oraz wskazanie działań publicznych osłabiających ich negatywny wpływ. W artykule przedstawiono ocenę zdolności do współpracy polskiego społeczeństwa, niezbędnej do tworzenia i upowszechniania innowacji. Ocenę zdolności do kooperacji przeprowadzono na podstawie wyników badań społecznych zawartych w Europejskim sondażu społecznym i Diagnozie społecznej. Wśród barier podstawowe znaczenie mają: niezdolność do współpracy, niski poziom zaufania i negatywne nastawienie społeczne do biznesu. Rozwój przedsiębiorczości można traktować jako warunek wstępny rozwoju innowacyjności. Mimo licznych deklaracji i realizacji pewnych pozytywnych działań przez rząd obecny model rozwoju prowadzi polską gospodarkę i społeczeństwo w przeciwnym kierunku. Model ten polega na ograniczaniu wolnego rynku, zwiększaniu udziału państwa w gospodarce i zdejmowaniu odpowiedzialności z jednostki. Buduje i utrwala się w ten sposób postawy roszczeniowe, a tym samym pozbawia społeczeństwo zdolności do konkurowania w globalnej gospodarce. Państwa jest coraz więcej tam, gdzie jego obecność wydaje się dyskusyjna. Natomiast tam, gdzie nie ma go kto zastąpić, państwo niejako abdykowało (wymiar sprawiedliwości, służba zdrowia). W tych warunkach bardzo pożądane stają się działania publiczne polegające na rozwijaniu umiejętności współpracy, zaufania i kapitału społecznego.
\end{abstract}

\begin{abstract}
This paper is aimed at identifying the cultural obstacles hindering the development of the innovative Polish economy and recommends public activity reducing their negative influence. The article presents the results of evaluation of capability for cooperation and confidence of Polish society coming from European Social Survey and Diagnoza Spoleczna [Social Diagnosis]. The most important cultural barriers are incapability for cooperation, low level of confidence and society's mind-set. The development of entrepreneurship can be treated as the fundamental condition for the development of innovation. The currently realized model of development is moving the economy and society in Poland in the opposite direction. It is based on restricting the free market, the extension of the government in the economy and taking responsibility from individuals. This phenomenon reduces our chances at an improved standard of living in the future and the ability to compete in the global economy. We can see the increasing participation of the state in sectors where its presence is debatable, however where no one can replace it, it seems that government has abdicated (the health care sector, jurisdiction). Under such circumstances it is increasingly important to develop public activity in direction of cooperation, social capital and confidence.
\end{abstract}


Słowa kluczowe: innowacyjność; kapitał społeczny; przedsiębiorczość; współpraca; zaufanie

Keywords: confidence; cooperation; entrepreneurship; innovativeness; social capital

Otrzymano: 6 stycznia 2015

Received: 6 January 2015

Zaakceptowano: 3 sierpnia 2015

Accepted: 3 August 2015

\section{Sugerowana cytacja / Suggested citation:}

Nowak, P. (2015). Kulturowe bariery rozwoju innowacyjności polskiej gospodarki. Prace Komisji Geografii Przemystu Polskiego Towarzystwa Geograficznego, 29(4), 85-102.

\section{WSTĘP}

Innowacje zyskują coraz więcej uwagi ze względu na ich rzeczywistą lub domniemaną rolę w rozwoju społeczno-gospodarczym krajów. Rywalizację na globalnych rynkach wygrywają te firmy, które są w stanie zaspokoić potrzeby klientów lepiej, szybciej i taniej. Stąd też sporą popularnością cieszą się obecnie tzw. skromne innowacje (ang. jugaad innovation), polegające na zaspokojeniu potrzeb za pomocą innowacyjnych produktów niskim kosztem (Bendyk, 2013). Poziom innowacyjności gospodarki jest wypadkową czynników o charakterze prawnym, ekonomicznym, społecznym, kulturowym i politycznym. Czynniki te są współzależne i mogą być osłabiane lub wzmacniane za pomocą odpowiednich działań z zakresu polityki publicznej, wpływających na zmianę postaw oznaczających otwartość, akceptację ryzyka, gotowość do eksperymentowania i współpracę.

Zaprezentowane w niniejszym artykule ujęcie problemu akcentuje czynniki pozaekonomiczne, a tym samym łagodzi istniejącą nierównowagę związaną z nadmierną ekspozycją czynników ekonomicznych, obecną w dyskursie dotyczącym warunków rozwoju innowacyjności. Niedocenianie czynników pozaekonomicznych prowadzi do nieefektywnych działań władz publicznych. Uwzględnienie m.in. czynników kulturowych jest koniecznym warunkiem prowadzenia racjonalnej polityki publicznej w stronę środowiska sprzyjającego współpracy i rozwojowi innowacyjnej gospodarki.

Opracowanie to poświęcone jest kulturowym uwarunkowaniom, mającym znaczenie przy tworzeniu i dyfuzji innowacji. Pomimo tego, że spora część innowacji powstaje przy udziale społecznym w otoczeniu biznesu, przedsiębiorstwa wciąż są głównymi kreatorami innowacji. Dobry klimat dla rozwoju przedsiębiorczości jest podstawowym warunkiem rozwoju innowacyjności. Ze względu na perspektywy rozwojowe kraju istotne znaczenie ma nastawienie do przedsiębiorczości społeczeństwa i instytucji publicznych. Rozwój innowacyjnych produktów wymaga z kolei umiejętności nawiązywania współpracy, zarówno w przedsiębiorstwach, między pracownikami, jak i pomiędzy przedsiębiorstwami, otoczeniem instytucjonalnym i klientami. Nakłada to na społeczeństwo konieczność współpracy. Skłonność do tworzenia owych warunków zależy od głęboko zakorzenionych postaw, mających charakter kulturowy. Stanowią one trwałe uwarunkowanie podejmowania współpracy w społeczeństwie. 
Celem opracowania jest identyfikacja przeszkód kulturowych hamujących rozwój innowacyjności polskiej gospodarki i ocena w tym kontekście zdolności do współpracy polskiego społeczeństwa. Nadmiar rywalizacji i konkurencji hamuje rozwój innowacji. Artykuł ma charakter analityczno-opisowy. Wykorzystano w nim dane zastane, pochodzące z Diagnozy społecznej, Europejskiego sondażu społecznego, Unijnej tablicy innowacyjności oraz badań prestiżu zawodów przeprowadzonego w 2013 roku przez Centrum Badania Opinii Społecznej (CBOS). W końcowej części artykułu sformułowane zostały propozycje potrzebnych działań ze strony władz centralnych i samorządowych rozwijających kapitał społeczny, zaufanie i zdolność do współpracy.

\section{STAN INNOWACYJNOŚCI POLSKIEJ GOSPODARKI}

Według J.A. Schumpetera (1960), autora Teorii rozwoju gospodarczego uznawanej za pierwsze kompleksowe ujęcie zjawiska innowacji, innowacje to „nowe kombinacje czynników" wytrącające ze stanu równowagi gałęzie, w których te kombinacje się pojawiają. Szeroko rozumiane przez autora innowacje to kombinacje produkcyjne i handlowe, a każda zmiana, która zmienia względną rzadkość czynników produkcji lub zwiększa użyteczność towarów istniejących, tworzy nową użyteczność.

Zakres znaczeniowy innowacji staje się coraz szerszy. Wynika to z tego, że obecnie lepiej rozumiemy wagę powiązań różnych aspektów rzeczywistości, zmian technologicznych i zmieniających się oczekiwań społecznych co do warunków życia. Zainteresowania innowacjami mocno wykraczają poza sferę techniczną i obejmują nowe obszary, takie jak ochrona środowiska, służba zdrowia czy sektor publiczny.

Najnowsze publikacje Eurostatu i Organizacji Współpracy Gospodarczej i Rozwoju (OECD) definiują innowacje w szeroki sposób, jako wdrożenie nowego lub znacznie ulepszonego produktu, procesu, nowej metody marketingowej bądź organizacyjnej w praktyce biznesowej, miejscu pracy i stosunkach zewnętrznych (Podręcznik Oslo, 2008). Definicja ta podkreśla praktyczny charakter innowacji, związany z przekształcaniem wiedzy w korzyści ekonomiczne.

Z punktu widzenia wpływu innowacji na zatrudnienie, dochody i produktywność istotny jest podział innowacji na trzy rodzaje: przełomowe, podtrzymujące i wydajnościowe (przyrostowe) (Christensen, 2012). We współczesnym świecie najwięcej jest innowacji wydajnościowych, których logika polega na znajdowaniu sposobów na obniżenie kosztów produkcji, tak aby produkt był dostępny dla jak najszerszej grupy odbiorców. Tego rodzaju innowacje mieszczą się w modelu biznesowym zorientowanym na klientów w Azji, Ameryce Południowej i Afryce. Wielkość i stopień nienasycenia rynku przesądza o korzyściach osiąganych przez przedsiębiorstwa. Coraz mniej jest innowacji przełomowych, które tworzyłyby rynki nowych produktów i które zwiększałyby zatrudnienie w krajach rozwiniętych, a coraz więcej nastawionych na zaspokojenie potrzeb w krajach rozwijających się. Skromne innowacje, tak popularne obecnie, mają charakter innowacji wydajnościowych.

Zazwyczaj odległe miejsce Polski w różnych rankingach stawia nas na pozycji państwa doganiającego, które musi nadrabiać dystans do krajów wysoko rozwiniętych (Nowak, 2012; 
Okoń, Horodyńska, Zachorowska-Mazurkiewicz, 2007; Siuta-Tokarska, 2010). Jednym z najpopularniejszych rankingów innowacyjności jest zestawienie gospodarek narodowych państw członkowskich opracowane przez Komisję Europejską. Od 2000 roku w Unii Europejskiej prowadzone są co roku badania poziomu innowacyjności gospodarek narodowych wybranych krajów. Do 2010 roku wyniki badań podawane były w Europejskiej tablicy innowacyjności (European Innovation Scoreboard), a później w Unijnej tablicy innowacyjności (Innovation Union Scoreboard). Europejska tablica innowacyjności obejmowała 29 wskaźników, z których 19 weszło bezpośrednio do Unijnej tablicy innowacyjności. W ramach tej ostatniej podane jest 25 wskaźników, podzielonych na trzy kategorie: czynniki sprzyjające, działalność firm i wyniki.

$\mathrm{Na}$ tle europejskim polska gospodarka jest wciąż bardzo mało innowacyjna. W Unijnej tablicy innowacyjności z 2014 roku Polska zajęła wśród państw członkowskich Unii Europejskiej 25 miejsce i została zaliczona do grona najmniej innowacyjnych gospodarek europejskich. Od samego początku prowadzenia badań w czołówce innowatorów znajdują się kraje skandynawskie. Na pierwszym miejscu w rankingu z 2014 roku znalazła się Szwecja, której sumaryczny indeks innowacyjności SII (Summary Innovation Index) wyniósł 0,755, natomiast najniższy odnotowała Bułgaria: 0,188 (wskaźnik ten przyjmuje wartości od 0 do 1). Polska w powyższym rankingu miała wskaźnik: 0,279, a więc trzy razy niższy niż Szwecja. Średnia dla UE 28 wynosiła 0,554 (zob. ryc. 1).

Ryc. 1. Sumaryczny indeks innowacyjności krajów członkowskich UE

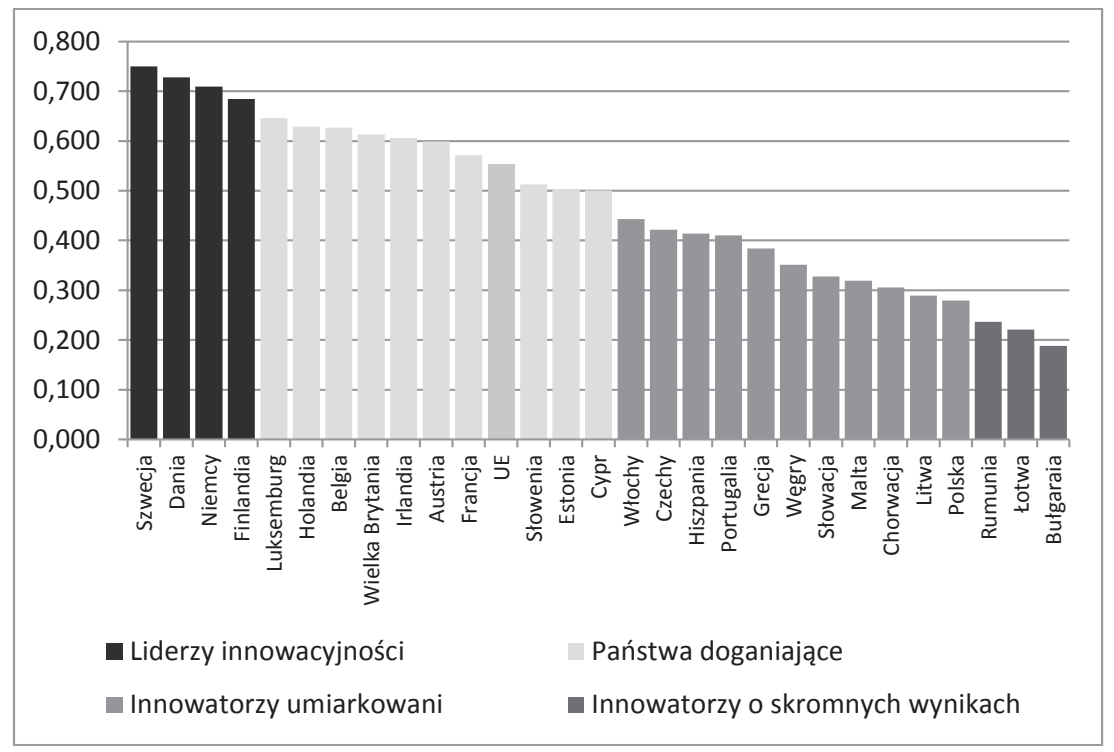

Źródło: Unijna tablica innowacyjności z 2014 roku

Relatywnie niska jakość systemu badań, niewielki poziom współpracy i przedsiębiorczości oraz mała liczba innowatorów to najsłabsze elementy naszego systemu innowacji na tle UE. 


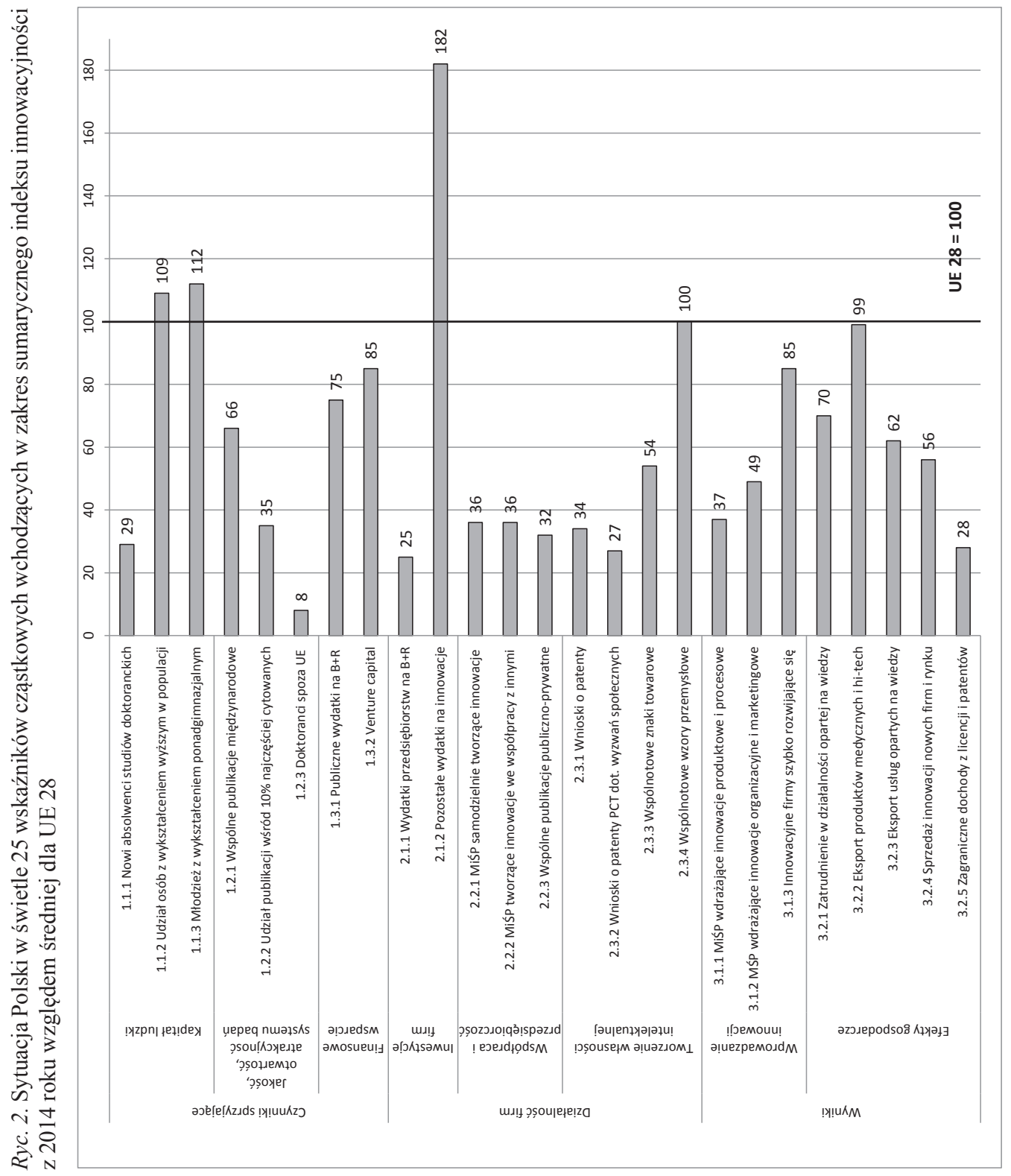

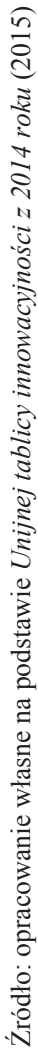


Dystans dzielący Polskę od państw unijnych jest bardzo widoczny w sferze współpracy i przedsiębiorczości. Nasz kraj cechuje niski poziom współdziałania między nauką a biznesem. Małe i średnie przedsiębiorstwa bardzo rzadko współpracują w ramach działalności innowacyjnej z innymi firmami lub instytucjami (zob. ryc. 2). Pod tym względem Polska wyróżnia się negatywnie na tle regionu, państw skandynawskich i średniej unijnej (zob. ryc. 3).

Ryc. 3. Odsetek innowacyjnych małych i średnich przedsiębiorstw, które współpracują z innymi podmiotami (Innovative SMEs collaborating with others) w Polsce i wybranych krajach UE

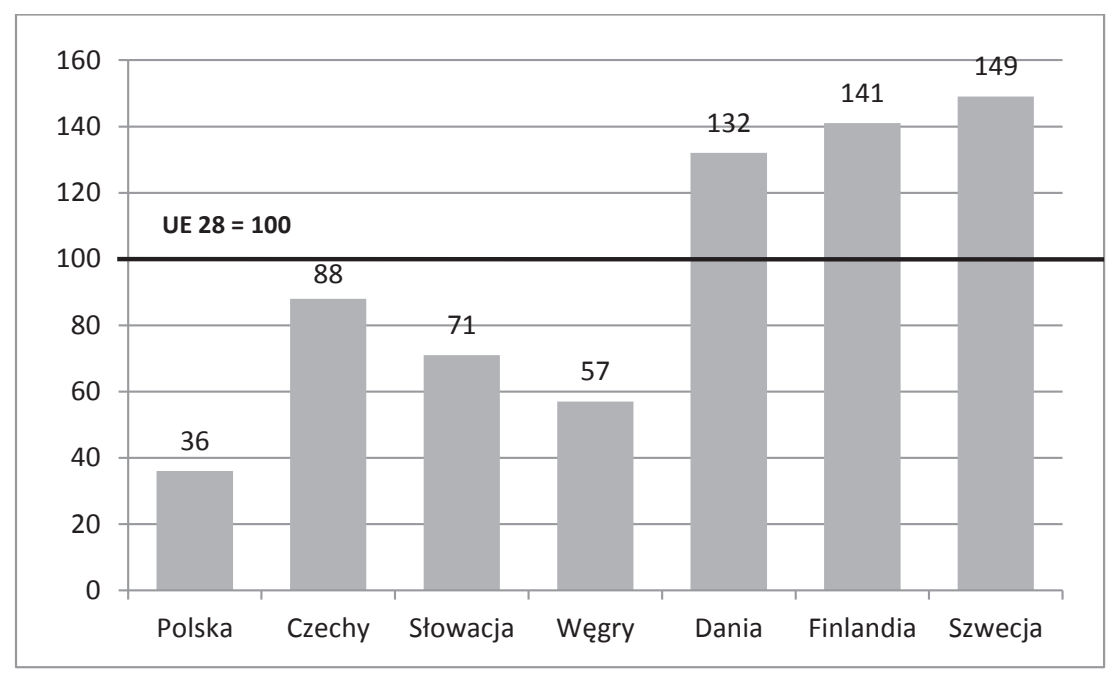

Źródło: opracowanie własne na podstawie Unijnej tablicy innowacyjności z 2014 roku (2015)

Konieczność współdziałania wynika z następujących okoliczności:

- innowacje powstają przy udziale większej niż dotychczas liczby uczestników,

- tworzenie innowacji wymaga krzyżowania się i dyfuzji większej niż dotąd liczby dziedzin wiedzy,

- więcej innowacji powstaje w ramach coraz bardziej zróżnicowanych mechanizmów (innowacje popytowe, społeczne, otwarte, tworzone w konsorcjach itd.),

- innowacje powstają w coraz bardziej zróżnicowanym środowisku (ośrodki transferu technologii, konsorcja badawcze, klastry, organizacje non profit, wiedzochłonne usługi biznesowe),

- w działalności innowacyjnej kładzie się coraz większy nacisk na decentralizację zarządzania projektami, elastyczność organizacji, samodzielność personelu, kreatywność, wzajemne zaufanie, komunikację i przywództwo.

Jakie są przyczyny takiej sytuacji? Wydaje się, że wielu polskich przedsiębiorców w ogóle nie interesuje się innowacyjnością. Ważny może być też brak pieniędzy i tradycyjny profil działalności danego biznesmena. Część polskich firm zyskuje swoją podstawową przewagę konkurencyjną dzięki niskim kosztom wytwarzania, nie wynika ona niestety z ciągłego podnoszenia jakości produktów, siły stworzonej marki czy kapitałochłonnych inwestycji 
w rozwój technologii (Okoń-Horodyńska, Zachorowska-Mazurkiewicz, 2008). Jednocześnie warto odnotować, że Polska na tle europejskim odznacza się wyjątkowo niskim poziomem kapitału społecznego, co zasadniczo zmniejsza zdolność obywateli do wspólnego działania.

Dowodem kulturowych ograniczeń tworzenia innowacji w firmach są wyniki badań J. Hryniewicza (2007) na temat kultury folwarczno-pańszczyźnianej w polskich przedsiębiorstwach. D. Batorski (2013) również odnosi się do przedsiębiorstw w kwestii tak pożądanej obecnie otwartości i dzielenia się własnymi zasobami z innymi. Zwraca on uwagę, że nie tylko instytucje publiczne powinny realizować ideę otwartości, ale że taka praktyka powinna cechować też firmy, bo to się po prostu opłaca.

Podobnie niezbyt optymistyczne dane przynoszą badania postrzegania innowacji przez przedsiębiorców. Z analizy Polskiej Agencji Rozwoju Przedsiębiorczości (PARP) wynika, że do zewnętrznych czynników sprzyjających poprawie potencjału innowacyjności polskiego społeczeństwa można zaliczyć w ostatnim czasie zwiększenie dostępu do nowoczesnych mediów i powolny wzrost mobilności i pluralizmu społecznego, natomiast głównymi barierami są tu obniżający kreatywność system nauczania oraz niski kapitał społeczny (Drozdowski, Zakrzewska, Puchalska, Morchat, Mroczkowska, 2010). Budowa innowacyjnej gospodarki to wyzwanie trudne i czasochłonne, przy czym poprawie sytuacji nie sprzyja obecny model kształcenia, kładący nacisk na indywidualne osiągnięcia i znikomy zakres nauki współpracy (Garbicz, 2013).

Bardzo dużym ograniczeniem jest zachowawcze, nastawione na przetrwanie podejście polskich przedsiębiorstw na rynku, a także struktury organizacyjne firm, często nastawione na premiowanie krótkookresowych sukcesów i na postawy konformistyczne. Znaczną barierą dla innowacyjności jest też w tym kontekście niedocenianie przez wielu pracodawców znaczenia inwestycji w szkolenie kadry zarządzającej (Plawgo, Kornecki, 2010), która często nie dostrzega korzyści płynących z innowacji i podejmowania ryzyka, natomiast jest nastawiona na przetrwanie i powielanie już istniejących wzorców (Bukowski, Szpor, Śniegocki, 2014).

Na polskim rynku niewiele podmiotów gospodarczych prowadzi działalność inwestycyjną i innowacyjną w skali zapewniającej rozwój, ponadto wciąż większość firm nie działa na podstawie długofalowych planów rozwoju. Przekłada się to na mniejszą konkurencyjność gospodarki. Im mniejsza firma, tym bariery te są bardziej odczuwalne. Prawidłowość ta obserwowana jest w całej Unii Europejskiej.

Innowacyjność jest narzędziem, które poprawia konkurencyjność. Istnieje ścisły związek między tymi dwiema cechami gospodarek (Geodecki, Hausner i in., 2013). Kraje mające wysoką pozycję w rankingach innowacyjności są też zazwyczaj wysoko notowane w rankingach konkurencyjności i poziomu życia. Przykłady państw wysoko rozwiniętych, jak Stany Zjednoczone, Japonia czy kraje skandynawskie, pokazują, że wśród czynników strukturalnych i makroekonomicznych innowacyjność oraz zasoby technologiczne kraju przesądzają o dużej międzynarodowej konkurencyjności jego gospodarki (Zioło, 2012; Rachwał, 2010). Między innowacyjnością a konkurencyjnością występuje dodatnie sprzężenie zwrotne - nawzajem się one napędzają. Państwo, które wejdzie na wysoki poziom spirali zależności, uzyskuje efekt kuli śniegowej. Osiągnięcie i utrzymanie przewagi konkurencyjnej opartej na innowacyjności wymaga ciągłego wynalazczego wysiłku. 


\section{ROSNĄCY SZACUNEK DLA PRZEDSIĘBIORCZOŚCI}

Mimo pojawiania się nowych mechanizmów i źródeł powstawania oraz upowszechniania innowacji głównymi aktorami innowacyjnego spektaklu pozostają nadal przedsiębiorstwa. Ich rola w opartym na innowacjach rozwoju społeczno-gospodarczym kraju jest dominująca. Warunki korzystne dla rozwoju innowacji są podobne do warunków niezbędnych do rozwoju przedsiębiorczości. Stosunek społeczeństwa do przedsiębiorczości tworzy warunki konieczne do rozwoju innowacyjności.

Aby dowiedzieć się, jak polskie społeczeństwo postrzega przedsiębiorczość, firma Semiotic Solutions przeprowadziła w 2010 roku, na zlecenie PARP, badanie semiotyczne. Wynika z niego, że opinie o przedsiębiorczości oscylują pomiędzy dwoma skrajnymi biegunami: między przestarzałymi stereotypami a nowymi ideami obecnymi w otaczającej nas kulturze (Przedsiębiorczość, 2014). Z jednej strony nasze społeczeństwo znajduje się pod silnym wpływem zaszłości historyczno-kulturowych i pochodzącej z czasów PRL-u swoistej pogardy dla dorabiania się i pieniędzy. Z drugiej - idee obecne we współczesnej kulturze pokazują nowe perspektywy, przedstawiając biznes jako niezależność i nowy styl życia, który pozwala lepiej wykorzystywać czas i możliwości. Ze względu na wspomniane zaszłości historyczne kreatywność i innowacyjność nie są powszechnie wiązane z wizerunkiem przedsiębiorcy. Oznacza to, że polscy biznesmeni są pod kulturowym naciskiem poglądów z przeszłości. Znajdują się oni pod silnym wpływem pewnych utrwalonych wzorców i stereotypów obecnych w polskiej kulturze, które przeszkadzają im w realizacji nowoczesnej wizji przedsiębiorczości (Polak, Haber, 2014). Wizerunek przedsiębiorcy oszusta, chciwego i niegodziwego, jest historycznie głęboko zakorzeniony $\mathrm{w}$ naszej kulturze i jest istotną barierą w pozytywnym, nowoczesnym postrzeganiu przedsiębiorczości.

Informacji na temat prestiżu zawodów dostarczają cykliczne badania przeprowadzane przez CBOS. Ostatni taki sondaż odbył się w 2013 roku po pięcioletniej przerwie. Dzięki danym z ubiegłych lat możliwe było zestawienie obecnych wyników z poprzednimi i prześledzenie zmian, jakie dokonują się w społecznym odbiorze różnych zawodów.

Obecna hierarchia zawodów nieco różni się od tej, którą Polacy wyznaczali poszczególnym profesjom pięć lat temu. Daje się przede wszystkim zauważyć dość powszechny ogólny wzrost prestiżu uwzględnionych w badaniu zawodów. Po porównaniu wyników ankiet z lat 2008 i 2013 można stwierdzić, że większość zawodów z listy, w tym głównie profesje najczęściej występujące w społeczeństwie, zyskała na uznaniu społecznym.

Zawody, których pozycja jest dziś wyraźnie lepsza niż pięć lat temu, to głównie te polegające na pracy fizycznej oraz te, które kojarzą się z przedsiębiorczością. W porównaniu z rokiem 2008 zyskały na prestiżu profesje: robotnik wykwalifikowany i niewykwalifikowany, właściciel małego sklepu, przedsiębiorca - właściciel dużej firmy (wzrost poważania o 7 punktów) (zob. ryc. 5).

Na prestiżu zyskują poszukiwane na rynku lub umożliwiające samodzielność zawody związane z pracą fizyczną. Zapewne głównie z powodu sytuacji na rynku pracy rośnie w ostatnich latach uznanie dla profesji wymagających konkretnych kwalifikacji, dających 
Ryc. 4. Hierarchia zawodów wg poważania społecznego

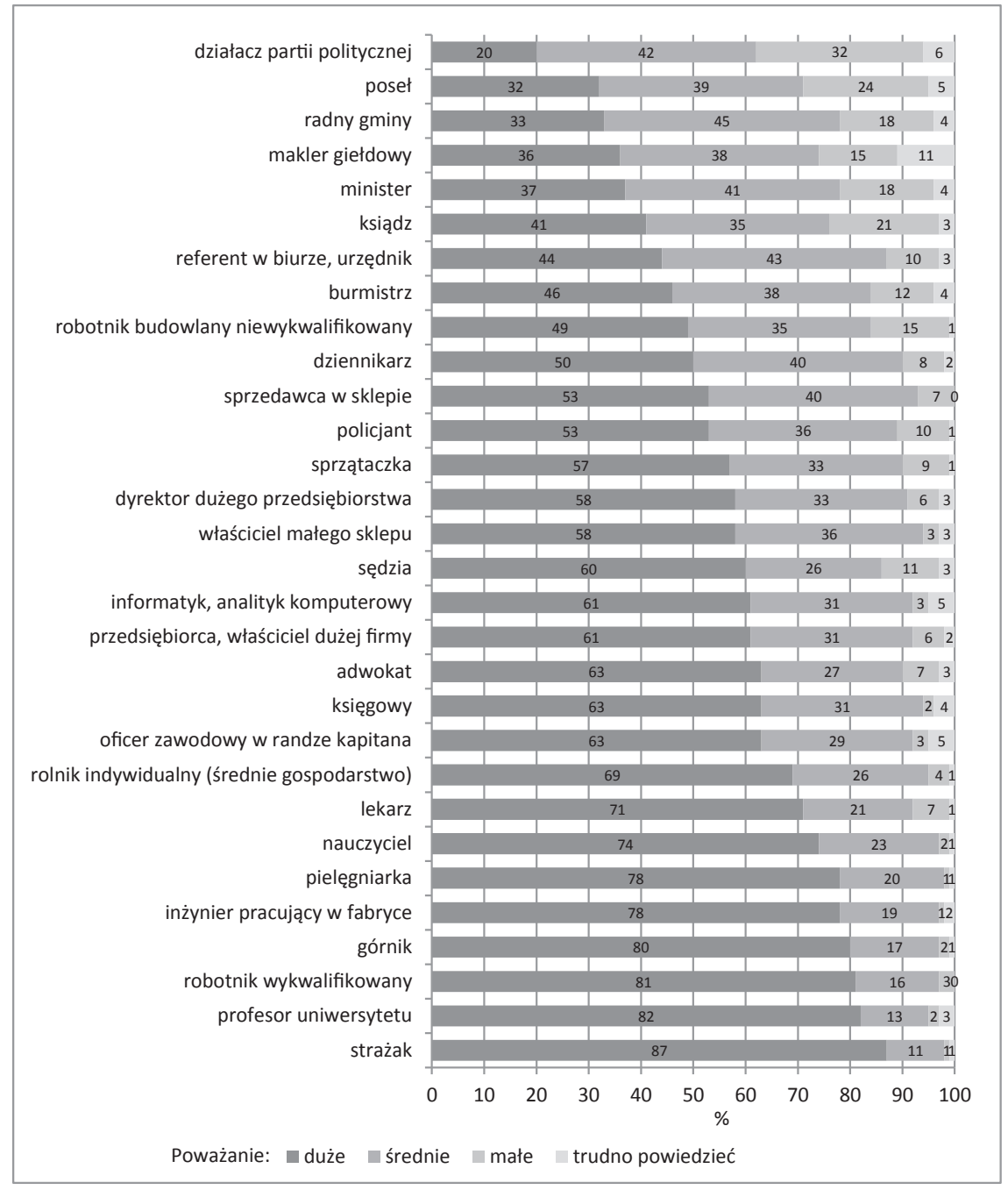

Źródło: opracowanie własne na podstawie Prestiżu zawodów (2014)

Ryc. 5. Zmiana prestiżu przedsiębiorcy

\begin{tabular}{|c|c|c|c|c|c|c|c|c|c|c|c|c|c|c|c|c|c|c|c|c|}
\hline \multirow{2}{*}{ ranga zawodów } & \multicolumn{10}{|c|}{ Poważanie } \\
\cline { 2 - 3 } & \multicolumn{10}{|c|}{ duźe } \\
\hline \multirow{2}{*}{ rok } & 95 & 96 & 99 & 08 & 13 & 95 & 96 & 99 & 08 & 13 & 95 & 96 & 99 & 08 & 13 & 95 & 96 & 99 & 08 & 13 \\
\hline & \multicolumn{10}{|c|}{ trudno powiedzieć } \\
\hline $\begin{array}{l}\text { przedsiębiorca, } \\
\text { właściciel dużej firmy }\end{array}$ & $\mathbf{4 5}$ & $\mathbf{3 9}$ & $\mathbf{4 8}$ & $\mathbf{5 4}$ & $\mathbf{6 1}$ & $\mathbf{4 1}$ & $\mathbf{4 7}$ & $\mathbf{3 9}$ & $\mathbf{3 4}$ & $\mathbf{3 1}$ & $\mathbf{1 1}$ & $\mathbf{1 0}$ & $\mathbf{9}$ & $\mathbf{7}$ & $\mathbf{6}$ & $\mathbf{4}$ & $\mathbf{4}$ & $\mathbf{5}$ & $\mathbf{5}$ & $\mathbf{2}$ \\
\hline
\end{tabular}

Źródło: opracowanie własne na podstawie Prestiżu zawodów (2014) 
możliwość zatrudnienia lub samozatrudnienia, a także dla działalności gospodarczej oraz zawodów kojarzonych ze sferą produkcyjną. Powyższe wyniki wskazują na poprawę klimatu dla przedsiębiorczości i rosnącą przychylność społeczeństwa.

\section{OCENA ZDOLNOŚCI DO WSPÓŁPRACY W ŚWIETLE WYNIKÓW BADAŃ DOTYCZĄCYCH ZAUFANIA}

Wśród przyczyn niskiej innowacyjności upatruje się najczęściej czynników technicznych, finansowych i instytucjonalno-prawnych. Autorzy raportu Kurs na innowacje. Jak wyprowadzić Polskę z rozwojowego dryfu? za główne tego powody uważają słabą jakość instytucji publicznych oraz brak dobrego otoczenia organizacyjno-instytucjonalnego (Geodecki, Gorzelak i in., 2012). Odpowiedź ta nie uwzględnia czynników kulturowych. Same czynniki instytucjonalne nie tłumaczą, dlaczego Polacy nie zachowują się kreatywnie i innowacyjnie. Otoczenie instytucjonalne ma duże znaczenie, ale innowacyjność, która w dużej mierze opiera się na zaufaniu i umiejętności współpracy, nie zależy głównie od warunków instytucjonalnych, ale od postaw społecznych. Odpowiedzi na pytanie, dlaczego Polska, mimo swoich mocnych stron w postaci relatywnie dobrze wykształconego społeczeństwa i względnie wysokich wydatków na inwestycje, cechuje się niską innowacyjną gospodarką, należy szukać gdzie indziej.

Powodem tej sytuacji są niedostatki kapitału społecznego w naszym kraju, a jego deficyt staje się poważną barierą rozwojową. Co więcej, jak sugeruje J. Czapiński, może spowodować zahamowanie wzrostu wraz z wyczerpaniem się innych źródeł rozwoju, przede wszystkim opartych na kapitale ludzkim i niskich kosztach pracy (2011: 253-285).

Kapitał społeczny stanowi fundament społeczeństwa obywatelskiego i innowacyjnej gospodarki. Pojęcie to nie jest ściśle zdefiniowane. Mieści się w nim wszystko to, co decyduje o dobrych relacjach społecznych, dbaniu o dobro wspólne i współpracy. Kapitał społeczny jest osadzony w aktualnych i potencjalnych zasobach, istniejących w sieciach relacji posiadanych przez jednostkę, które mogą być uruchomione przez celowe działanie (Nahapiet, Ghoshal, 1998; Lin, 2001). Z ekonomicznego i społecznego punktu widzenia jest on ważny, ponieważ obniża koszty transakcyjne, zmniejsza koszty zabezpieczenia przed ryzkiem, wspomaga długoterminowe inwestycje i dyfuzję wiedzy, podnosi spójność społeczną i sprzyja społecznej kontroli działania władzy. Proces tworzenia i upowszechniania innowacji zależy od społecznego kapitału, od zdolności do mobilizacji ludzi i idei, elastyczności budowania zespołów, kultury współdziałania i kontraktu.

Podstawą kapitału społecznego jest zaufanie W ciągu ostatnich 20 lat stało się ono jednym z najczęściej analizowanych zjawisk socjologicznych na świecie. Przesłanką ważności zaufania jest traktowanie go jako jednego z najważniejszych czynników niezbędnych do nawiązywania stosunków i podtrzymywania więzi z innymi ludźmi oraz z całymi narodami. Najwięcej materiału empirycznego dotyczącego zaufania dostarczyły wyniki międzynarodowego badania World Values Survey z lat dziewięćdziesiątych. Potwierdziły one występowanie związku między poziomem zaufania a stopniem demokratyzacji, rozwoju 
ekonomicznego, zamożności, a przede wszystkim rodzajem systemu społeczno-politycznego (Domański, 2014: 8).

Zaufanie oznacza redukcję niepewności i ryzyka, stanowi więc ważne dobro, determinantę funkcjonowania jednostek i systemów społecznych. Najbardziej wymierne korzyści płynące z dużego zaufania znajdziemy w sferze ekonomicznej. Większe zaufanie pociąga za sobą mniejsze koszty transakcyjne, które ponosi się przy zawieraniu i realizacji kontraktów. Polega to m.in. na skróceniu czasu negocjacji i łatwiejszym porozumiewaniu się stron, mniejsza jest również potrzeba monitoringu na etapie wykonywania umowy. Zaufanie to także większe prawdopodobieństwo dotrzymywania umów, a więc podnosi bezpieczeństwo transakcji. Zaufanie jest ważnym dobrem - zarówno dla jednostek jak i dla społeczeństw porównywalnym z dochodami, wykształceniem czy prestiżem społecznym. Jednak zasadą jest, że dobra cenione i ważne nie są powszechnie dostępne, czego odzwierciedleniem są nierówności zaufania między krajami (Domański, 2014: 10).

Głównymi źródłami informacji na temat zaufania są wyniki badań pochodzące z Europejskiego sondażu społecznego (Sztabiński, Sztabiński, 2014) i Diagnozy społecznej (Czapiński, Panek, 2013). Największe zaufanie występuje w krajach skandynawskich, a najmniejsze - w krajach postkomunistycznych i śródziemnomorskich. Polska na tle europejskim odznacza się wyjątkowo niskim poziomem zaufania. Jak pokazują wyniki Diagnozy społecznej, tylko kilkanaście procent Polaków jest przekonanych, że można ufać innym ludziom. Ten brak zaufania przekłada się na słabą zdolność do mobilizowania i wykorzystywania zasobów należących do innych osób. Dotyczy to przede wszystkim słabych więzi z osobami, z którymi rzadziej utrzymuje się kontakt i z którymi ma się mniej wspólnych znajomych.

Polska nie spełnia kryteriów społeczeństwa innowacyjnego. Pod względem ogólnego zaufania zajmujemy jedno z ostatnich miejsc wśród krajów objętych badaniem Europejskiego sondażu społecznego (zob. ryc. 6). Z opinią, że większości ludzi można ufać, zgadzało się wg Diagnozy społecznej z 2013 roku zaledwie 10,5\%. respondentów w latach 2003 i 2005, 12\% w 2007 roku, 13\%. w latach 2009 i 2011, a 12,2\% w 2013 roku. Według Europejskiego sondażu społecznego w 2012 roku było to 18\%, czyli trzy razy mniej niż w Danii, Norwegii i Finlandii, krajach o bardzo wysokim poziomie życia.

Występuje też zbieżność między miejscem państwa w Unijnej tablicy innowacyjności a wynikiem zaufania. Kraje najbardziej innowacyjne to te, które znajdują się w czołówce rankingów zaufania, takie jak: Dania, Finlandia i Szwecja.

Znacznie rzadziej niż przedstawiciele innych społeczeństw UE Polacy wierzą w dobre intencje bliźnich. Zaledwie 14\% rodaków wg Europejskiego sondażu społecznego z 2012 roku (mniej tylko w Bułgarii i Portugalii) i nieco mniej wg Diagnozy społecznej z 2011 roku (13\%), a trochę więcej wg Diagnozy z 2013 roku (16\%) jest przekonanych, że ludzie najczęściej starają się być pomocni (zob. ryc. 7). 
Ryc. 6. Odsetek osób w wieku 16 i więcej lat ufających innym ludziom

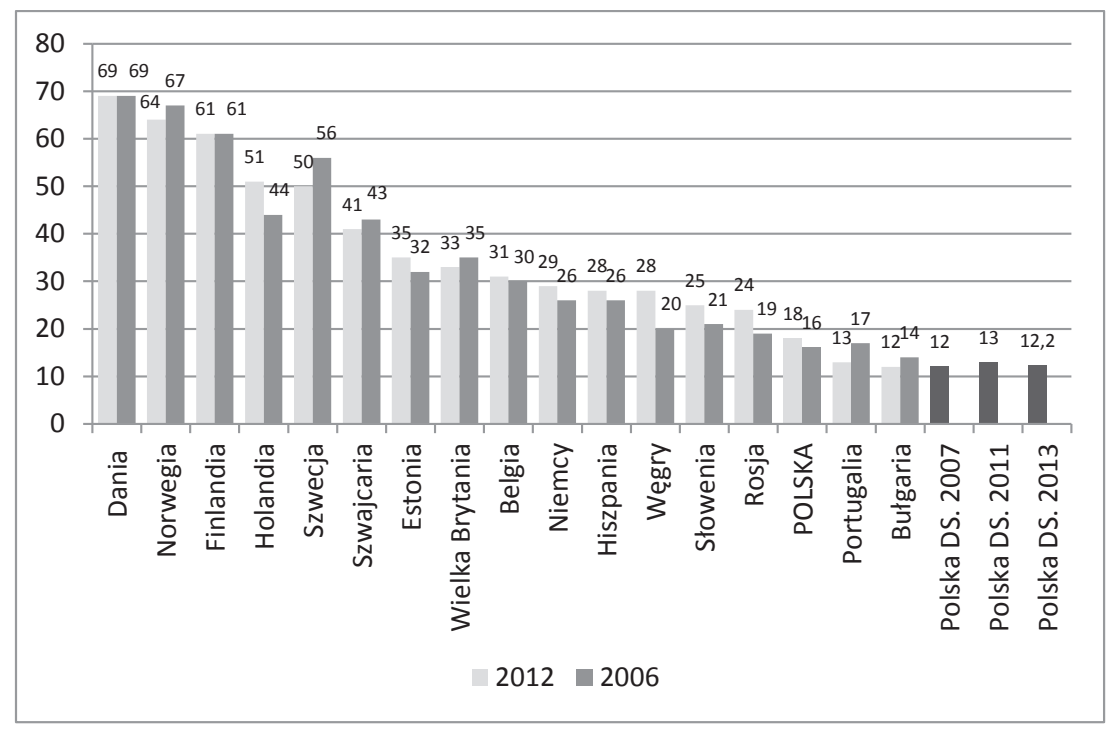

Źródło: Czapiński, Panek (2013: 286)

Ryc. 7. Odsetek osób w wieku 16 lat i więcej przekonanych, że ludzie najczęściej starają się być pomocni

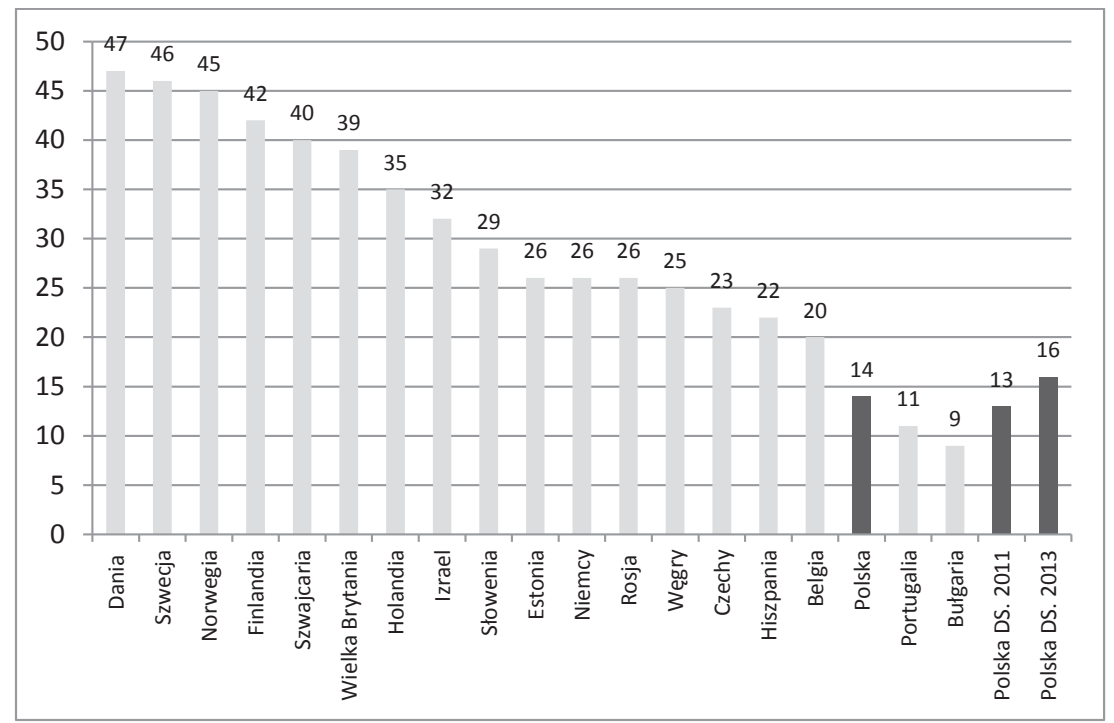

Źródło: Czapiński, Panek (2013: 286) 
Innowacyjność i kreatywność są w dzisiejszych czasach w coraz większym stopniu wynikiem współpracy. Niski poziom uogólnionego zaufania nie daje możliwości mobilizacji i wykorzystywania wolnych zasobów. Słaba zdolność współpracy i brak kapitału społecznego przekładają się na małe wykorzystanie zasobów indywidualnych jednostek. Osoby mające w swoim bliższym i dalszym otoczeniu innych posiadających potrzebne im zasoby, wiedzę, umiejętności, technologię, nie mają do nich dostępu. Niski kapitał społeczny jest poważnym ograniczeniem zarówno przy rozprzestrzenianiu, jak i przy tworzeniu innowacji. Niedostatkiem tego kapitału można tłumaczyć słabe przystosowanie innowacji do oczekiwań społecznych i ich mniejsze możliwości rozprzestrzenienia. Tworzenie nowości wymaga kontaktu $\mathrm{z}$ otoczeniem, testowania i eksperymentowania oraz korzystania ze sprzężenia zwrotnego, z informacji o tym, jak inni ludzie odbierają daną innowację. Powstawanie i upowszechnianie się innowacji to coraz bardziej złożony proces, który wymaga kontaktów między ludźmi, w tym wymiany opinii, przyjaznego wsparcia czy wzajemnego dostępu do indywidualnych zasobów wiedzy i umiejętności. Zgodność z wartościami, dotychczasowymi doświadczeniami, potrzebami oraz wcześniejszymi technologiami jest jednym z czynników sukcesu w dyfuzji innowacji (Batorski, 2013).

Kapitał ludzki jest ważniejszym niż kapitał społeczny czynnikiem rozwoju w państwach uboższych, do których ciągle jeszcze można zaliczyć nasz kraj. Po przekroczeniu jednak pewnego progu zamożności decydującego znaczenia dla dalszego rozwoju nabierze kapitał społeczny. To wyjaśnia, dlaczego do tej pory Polska rozwijała się w niezłym tempie, średnio 4\% PKB rocznie w ciągu ostatnich 25 lat, pomimo bardzo niskiego poziomu kapitału społecznego. Według J. Czapińskiego (2011) Polska przekroczy próg zamożności, powyżej którego dalsze inwestowanie w kapitał ludzki przestanie wystarczać do podtrzymania rozwoju, prawdopodobnie za osiem lat. Tyle mniej więcej zostało nam czasu na budowanie kapitału społecznego, jeśli chcemy się dalej rozwijać.

\section{Dzialania państwa na rzecz rozwoju opartego na innowacjach - wspieranie współpracy i wzmacnianie zaufania}

Możliwości kształtowania umiejętności współpracy oraz budowania zaufania ma w pewnym stopniu państwo. Temu celowi powinno służyć:

- wprowadzenie jako dominującego nauczania opartego na pracy projektowej i grupowym rozwiązywaniu problemów,

- tworzenie i wspieranie form dialogu społecznego - decentralizacja i rozwijanie partycypacyjnego modelu prowadzenia polityki, miotami.

- wspieranie klastrów i stowarzyszeń opartych na współpracy między różnymi pod-

W literaturze amerykańskiej uczenie metodą projektu (Project Based Learning) w dużym stopniu pokrywa się z organizacją uczenia przez rozwiązywanie problemu (Problem Based Learning). W obu przypadkach projekt rozpoczyna wiodące pytanie lub zadanie, które wymaga od uczniów zgłębienia kluczowych dla danej dziedziny pojęć i zagadnień oraz zebrania informacji na ten temat (Duch, Groh, Allen, 2001). Sprawia to, że młodzi ludzie 
dowiadują się, jak się uczyć, jak współpracować z innymi i jak zastosować zdobywane W szkole wiadomości i umiejętności do rozwiązania problemów, z którymi stykają się (lub mogą się w przyszłości zetknąć) w życiu osobistym, zawodowym lub w aktywności obywatelskiej.

Upowszechnienie pracy zespołowej w ramach projektów i uczenie przez rozwiązywanie problemów jest odpowiedzią edukacji na pilną potrzebę rozwoju kapitału społecznego w Polsce. W rządowej strategii Polska 2030 zostało to uznane za jedno z dziesięciu kluczowych wyzwań w perspektywie najbliższych 20 lat (Boni, 2009). Praca metodą projektu buduje kapitał społeczny, uczy bowiem młodych ludzi współpracy, wymaga dzielenia się zadaniami i odpowiedzialnością, uczy samoorganizacji, wzajemnej pomocy i zaufania. Zachęca do poznawania świata poza murami szkoły i działania na rzecz innych. Z tego punktu widzenia szczególne znaczenie mają prowadzone przez uczniów i studentów projekty społeczno-obywatelskie. Uczenie metodą projektu ma na świecie ugruntowaną pozycję. Jest popularne w wielu krajach europejskich, w tym głównie w szkołach skandynawskich, osiągających bardzo dobre wyniki zaufania i innowacyjności.

Uczenie metodą projektu lub uczenie przez rozwiązywanie problemu jest w polskiej oświacie rzadko stosowane. Wymaga ono dobrego przygotowania, a niekiedy i odwagi ze strony nauczyciela i uczniów. Dotychczas prowadzone w szkołach projekty mają często zubożony charakter, sprowadzają się do opisu danego zjawiska, nie obejmują zaś własnej oceny przez uczniów poruszanych kwestii, pokazania przyczyn i konsekwencji przedstawianych zagadnień. Uczniowie i studenci często bezkrytycznie przedstawią informacje znalezione w Internecie, natomiast nie potrafią się do nich odnieść.

Tworzenie forów i popularyzacja dialogu społecznego mieszczą się w rozwoju demokracji oraz społeczeństwa obywatelskiego, ale służą też lepszemu dostosowaniu prawnych i instytucjonalnych rozwiązań do potrzeb społecznych. W Polsce przeszkodami w rozwoju dialogu społecznego są: duża nieufność, brak dobrych nawyków oraz nadmierne upolitycznienie. Polityzacja sfery publicznej blokuje możliwość podejmowania współpracy ze względu na przenoszenie konfliktu politycznego w sferę społeczną i gospodarczą. Celem rozwiązań służących rozwijaniu dialogu ma być włączenie do niego różnych grup społecznych. Na przykład polityka energetyczna powinna uwzględniać interes narodowy (bezpieczeństwo energetyczne), interes producentów i dystrybutorów, ale też interes konsumentów. Nowoczesna forma tego dialogu wymaga, aby nie był on prowadzony, tak jak do tej pory, na zasadach korporatystycznych, tzn. by służył interesom partykularnym uczestników, ma służyć wspólnemu celowi. Dla perspektyw rozwojowych kraju ważne jest przedefiniowanie dialogu społecznego i wzrost jego znaczenia. Uzupełnieniem dialogu prowadzonego na płaszczyźnie rząd - pracodawcy - związki zawodowe w ramach Komisji Trójstronnej powinno być powołanie Krajowej Rady ds. Konkurencyjności Gospodarki, kierowanej przez premiera i skupiającej reprezentantów różnych środowisk (Geodecki, Hausner i in., 2013). Rada taka pracowałaby na rzecz strategii rozwoju i konkurencyjności gospodarki.

Kolejną kwestią zasługującą na wsparcie państwa jest rozwój klastrów. Zrozumienie idei funkcjonowania gospodarki sieciowej i kooperacyjnej w Polsce jest niewystarczające na tle europejskim. Większość inicjatyw klastrowych powstaje w oderwaniu od największych 
skupisk przedsiębiorstw, a klastry skupiają jedynie 1,6\% ogółu zatrudnionych (Dzierżanowski, 2012: 46). Przedsiębiorstwa nie dostrzegają korzyści płynących ze współpracy, a nadzieje przysłaniają obawy związane z udziałem w klastrze. Uczestniczące w klastrze firmy mogą liczyć na dostęp do wiedzy i doświadczenia innych podmiotów, dostęp do zasobów wykwalifikowanych pracowników i infrastruktury społecznej. W Polsce brak jest doświadczeń w realizacji projektów sieciowych, dlatego państwo powinno przygotowywać do tej roli specjalnie wyszkolonych koordynatorów.

\section{ZAKOŃCZENIE}

Innowacyjna gospodarka wymaga różnorodności i współpracy między ludźmi. Potrzeba ta wynika z wielu przyczyn. Chociażby z takiej, że innowacyjne produkty są często bardzo złożone i muszą być tworzone przez multidyscyplinarne zespoły. Gromadzenie i weryfikacja nowych koncepcji czy rozwiązań również wymagają gospodarki sieciowej. Z makroekonomicznego punktu widzenia w warunkach braku umiejętności współpracy występują straty dobrobytu, ponieważ część potencjału rozwojowego nie jest w pełni wykorzystana. Jak pokazują wyniki badań, społeczeństwa krajów europejskich różnią się istotnie pod względem umiejętności współpracy. Niestety, nasze społeczeństwo wypada słabo na tle krajów europejskich pod względem poziomu kapitału społecznego. Polską gospodarkę charakteryzuje molekularny model rozwoju oparty na własności prywatnej i indywidualizmie.

Edukacja odgrywa podstawową rolę w budowaniu niezbędnych zasobów dla innowacyjnej gospodarki, tworzy podstawy rozwoju społeczno-gospodarczego kraju. Rola edukacji znajduje odzwierciedlenie w charakterze gospodarek krajów wysoko rozwiniętych, określanych mianem gospodarek opartych na wiedzy. Znaczenie wiedzy widać w badaniach dotyczących kapitału intelektualnego i społecznego. Zarówno wiedza techniczna, jak i empatia, umiejętności współdziałania oraz współpracy z innymi ludźmi zyskują na znaczeniu.

Obowiązujący w Polsce model kształcenia przegrywa z nadmiarem danych. Polega on na zalewaniu uczniów masą informacji, często mało przydatnych i o niskiej jakości. Nadmiar wiadomości nie podnosi jakości kształcenia, prowadzi tylko do frustracji uczniów. Brakuje koordynacji programów edukacyjnych i właściwego doboru nauczanych treści. Szkoła powinna kłaść większy nacisk na rozwijanie umiejętności pracy zespołowej. Uczenie metodą projektu lub uczenie przez rozwiązywanie problemu jest rzadko stosowane w polskiej oświacie.

Zarówno w dziedzinie edukacji, jak i w innych obszarach życia społeczno-gospodarczego w tworzeniu kultury współpracy dużą rolę odgrywa państwo. Trafna polityka społeczno-gospodarcza wymaga uwzględniania opinii różnych środowisk. Sprzyja temu kultura współpracy. Jak pokazują wyniki badań, dialog społeczny w Polsce stoi na niskim poziomie. Niestety, nasilają się negatywne tendencje niszczące kapitał społeczny, napędzane przez podziały polityczne. Ma miejsce utrwalanie postaw roszczeniowych i nakręcanie oczekiwań społecznych niemożliwych do zrealizowania. Działalność gremiów opiniotwórczych w postaci rad lub forów doradczych ma często charakter fasadowy. Spór emocjonalny dominuje i wypiera spór merytoryczny. 
Współpraca pomiędzy przedsiębiorstwami, zgodna z prawem i etyką, stwarza szanse na korzyści dla biorących w niej udział uczestników i całego społeczeństwa. Niestety, jak wynika z zaprezentowanych danych, polskie firmy kooperują ze sobą w małym stopniu. Zachowania rynkowe przedsiębiorstw polegają głównie na konkurencji, a nie na kooperacji. W tworzenie infrastruktury sprzyjającej współpracy powinien włączyć się samorząd terytorialny, budując odpowiednie ramy infrastrukturalne. Do inicjatyw podejmowanych przez jednostki samorządu terytorialnego można zaliczyć m.in. grupy doradcze do tworzenia strategii innowacji dla regionów, inicjatywy klastrowe i targi. Niezbędne jest popularyzowanie idei współpracy wśród przedsiębiorstw oraz przygotowanie kadr samorządowych, które pełniłyby funkcję animatorów i koordynatorów inicjatyw klastrowych. Uważam, że do tej pory działania w tym zakresie są zbyt skromne.

\section{Literatura \\ References}

Batorski, D. (2013). Kapitał społeczny i otwartość jako podstawa innowacyjności. W: P. Zadura-Lichota (red.). Świt innowacyjnego społeczeństwa. Trendy na najbliższe lata. Warszawa: Polska Agencja Rozwoju Przedsiębiorczości.

Bendyk, E. (2013). Innowacje w kryzysie. Paradoksy rozwoju. W: P. Zadura-Lichota (red.). Świt innowacyjnego społeczeństwa. Trendy na najbliższe lata. Warszawa: Polska Agencja Rozwoju Przedsiębiorczości.

Boni, M. (red.) (2009). Polska 2030: wyzwania rozwojowe. Kancelaria Prezesa Rady Ministrów.

Bukowski, M., Szpor, A., Śniegocki, A. (2014). Innowacyjność polskiej gospodarki. Ekonomia i Zarządzanie, 1, 6-20.

Christensen, C. (2012, 3 listopada). A capitalist's dilemma. Whoever wins on Tuesday. New York Times.

Czapiński, J. (2011). Miękkie kapitały a dobrobyt materialny: wyzwania dla Polski. W: J. Czarnota-Bojarska, I. Zinserling (red.). W kręgu psychologii społecznej. Warszawa: Wydawnictwa Uniwersytetu Warszawskiego.

Czapiński, J., Panek, T. (red.) (2013). Diagnoza społeczna 2013. Warunki i jakość życia Polaków. Quarterly of University of Finance and Management in Warsaw, 7.

Domański, H. (2014). Zaufanie między ludźmi. W: P.B. Sztabiński, F. Sztabiński (red.). Polska Europa. Wyniki Europejskiego sondażu społecznego 2002-2012. Warszawa: Wydawnictwo Instytutu Filozofii i Socjologii PAN.

Drozdowski, R., Zakrzewska, A., Puchalska, K., Morchat, M., Mroczkowska, D. (2010). Wspieranie postaw proinnowacyjnych przez wzmacnianie kreatywności jednostki. Warszawa: Polska Agencja Rozwoju Przedsiębiorczości. Pozyskano z http://www.parp.gov.pl/files/74/81/380/9721.pdf

Duch, B.J., Groh, S.E., Allen, D.E. (2001). The Power of Problem-Based Learning. Sterling: Stylus Publishing.

Dzierżanowski, M. (2012). Kierunki izałożenia polityki klastrowej w Polsce do 2020 roku. Rekomendacje grupy roboczej ds. polityki klastrowej. Warszawa: Polska Agencja Rozwoju Przedsiębiorczości. Pozyskano z http://poig.parp.gov.pl/files/74/81/545/14669.pdf

Garbicz, A. (2013). Gospodarka w czasie turbulencji. Instytut Idei. Warszawa: Instytut Obywatelski.

Geodecki, T., Gorzelak, G., Górniak, J., Hausner, J., Mazur, S., Szlachta, J., Zaleski, J. (2012). Kurs na innowacje. Jak wyprowadzić Polskę z rozwojowego dryfu? Kraków: Fundacja Gospodarki i Administracji Publicznej. 
Geodecki, T., Hausner, J., Majchrowska, A., Marczewski, K., Piątkowski, M., Tchorek, G., Tomkiewicz, J., Weresa, M. (2013). Konkurencyjna Polska. Jak awansować w światowej lidze gospodarczej? Kraków: Fundacja Gospodarki i Administracji Publicznej.

Hryniewicz, J. (2007). Stosunki pracy w polskich organizacjach. Warszawa: Wydawnictwo Naukowe Scholar.

Lin, N. (2001). Social capital: a theory of social structure and action. Cambridge: Cambridge University Press.

Nahapiet, J., Ghoshal, S. (1998). Social capital, intellectual capital and the organizational advantage. Academy of Management Review, 23(2).

Nowak, P. (2012). Poziom innowacyjności polskiej gospodarki na tle krajów UE. Prace Komisji Geografii Przemystu Polskiego Towarzystwa Geograficznego, 19, 142-152.

Okoń-Horodyńska, E., Zachorowska-Mazurkiewicz, A. (2007). Innowacje w rozwoju gospodarki i przedsiębiorstw: sily motoryczne i bariery. Warszawa: Instytut Wiedzy i Innowacji.

Okoń-Horodyńska, E., Zachorowska-Mazurkiewicz, A. (2008). Tendencje innowacyjnego rozwoju polskich przedsiębiorstw. Warszawa: Instytut Wiedzy i Innowacji.

Plawgo, B., Kornecki, J. (2010). Wykształcenie pracowników a pozycja konkurencyjna przedsiębiorstw. Warszawa: Polska Agencja Rozwoju Przedsiębiorczości. Pozyskano z http://badania.parp.gov.pl/ files/74/75/76/487/494/10557.pdf

Podręcznik Oslo. Zasady gromadzenia i interpretacji danych dotyczacych innowacji (2008). OECD/ Eurostat, wydanie 3, thum. D. Przepiórkowska.

Polak, K., Haber, A. (2014, 15 listopada). Polskie spojrzenie na przedsiębiorczość. Harward Business Review Polska. Pozyskano z http://www.hbrp.pl/news.php?id=643

Prestiż zawodów (2014; 2015, 5 stycznia). Komunikat badań BS 164/2013. CBOS. Pozyskano z http:// www.cbos.pl/SPISKOM.POL/2013/K_164_13.PDF

Przedsiębiorczość w kulturze. Wyniki audytu semiotycznego przedsiębiorczości (2014, 12 listopada). Semiotic Solutions Polska. Pozyskano z http://www.pte.org.pl/attachments/article/677/ Badania\%20semiotyczne $\% 20 \mathrm{w} \% 20$ ewaluacji.pdf

Rachwał, T. (2010). Struktura przestrzenna i działowa przemysłu Polski na tle Unii Europejskiej w dwudziestolecie rozpoczęcia procesów transformacji systemowej. Prace Komisji Geografii Przemystu Polskiego Towarzystwa Geograficznego, 16, 105-124.

Schumpeter, J.A. (1960). Teoria rozwoju gospodarczego. Warszawa: Państwowe Wydawnictwo Naukowe.

Siuta-Tokarska, B. (2010). Konkurencyjność i innowacyjność polskiej gospodarki na tle wybranych gospodarek zagranicznych. W: A.P. Balcerzak, E. Rogalska (red.). Stymulowanie innowacyjności i konkurencyjności przedsiębiorstwa $w$ otoczeniu globalnej gospodarki wiedzy. Toruń: Wydawnictwo Naukowe Uniwersytetu Mikołaja Kopernika.

Sztabiński, P.B, Sztabiński, F. (red.) (2014). Polska - Europa. Wyniki Europejskiego Sondażu Społecznego 2002-2012. Warszawa: Wydawnictwo Instytutu Filozofii i Socjologii PAN.

Unijna tablica innowacyjności z 2014 roku (2015, 4 stycznia). Pozyskano z http://ec.europa.eu/enterprise/policies/innovation/files/ius/ius-2014_en.pdf

Zioło, Z. (2012). Miejsce innowacyjności w kształtowaniu procesu rozwoju gospodarczego układów przestrzennych. Prace Komisji Geografii Przemystu Polskiego Towarzystwa Geograficznego, 20, 9-32.

Pawel Nowak, dr, Uniwersytet Pedagogiczny w Krakowie, Instytut Politologii, Katedra Ekonomii i Polityki Gospodarczej. Doktor nauk ekonomicznych w zakresie ekonomii, tytuł nadany przez Uniwersytet Ekonomiczny w Krakowie. Adiunkt w Katedrze Ekonomii i Polityki Gospodarczej Uniwersytetu Pedagogicznego w Krakowie. Zainteresowania naukowe: mikro- i makroekonomia, polityka gospodarcza i społeczna, przedsiębiorczość, integracja i globalizacja, niepewność i prawa konsumenta, innowacyjna gospodarka. 
Pawel Nowak, holds a Ph.D. in economics from the Cracow University of Economics. At present is employed at the Department of Economics and Economic Politics, Institute of Political Science, Pedagogical University of Cracow. Main research interests concern: mico and macroeconomics, economic and social politics, entrepreneurship, integration and globalization, uncertainty and consumer rights, innovative economy.

\section{Adres/address:}

Uniwersytet Pedagogiczny w Krakowie Instytut Politologii

Katedra Ekonomii i Polityki Gospodarczej

ul. Podchorążych 2, 30-084 Kraków, Polska

e-mail: gelb@wp.pl 